\title{
Forest type affects prey foraging of saddleback tamarins, Saguinus nigrifrons
}

\author{
Denis Kupsch • Matthias Waltert • Eckhard W. Heymann
}

Received: 15 May 2013/Accepted: 22 February 2014/Published online: 1 April 2014

(C) The Author(s) 2014. This article is published with open access at Springerlink.com

\begin{abstract}
Callitrichids can persist in secondary forests where they may benefit from elevated prey abundance. However, how tamarins forage for prey in secondary forest compared to primary forest has not been examined. Using scan and focal sampling, we compared prey foraging and capture success of two groups of Saguinus nigrifrons in north-eastern Peru: one ranging in primary forest, the other with access to a 10-year-old anthropogenic secondary forest. There was a trend for more prey search in the secondary forest, but prey feeding, capture success and size were lower compared to the primary forest. Tamarins avoided the forest floor, used vertical supports less often and searched on a lower variety of substrates in the secondary forest. In the secondary forest, tamarins did not capture flushed prey, which make up a substantial part of the total prey captures biomass in primary forests. Reduced prey capture success is unlikely to reflect reduced prey availability, since more Orthoptera were found in secondary forest through ultrasonic surveys. Therefore, the prey search activity of $S$. nigrifrons in young secondary forests seemed rather opportunistic, presumably influenced by altered predation patterns, vegetation structure, as well as prey diversity.
\end{abstract}

Electronic supplementary material The online version of this article (doi:10.1007/s10329-014-0416-4) contains supplementary material, which is available to authorized users.

D. Kupsch · E. W. Heymann

Behavioral Ecology and Sociobiology Unit, German Primate

Center, Göttingen, Germany

D. Kupsch $(\bowtie) \cdot$ M. Waltert

Department of Conservation Biology, Georg-August University

Göttingen, Bürgerstraße 50, 37073 Göttingen, Germany

e-mail: dkupsch@gwdg.de
Keywords Saguinus nigrifrons - Tamarin · Prey foraging - Secondary forest - Primary forest $\cdot$ Habitat use

\section{Introduction}

Human activities increasingly affect natural forest ecosystems of the tropics (Wright and Muller-Landau 2006; FAO 2007). In particular, timber harvesting and agriculture push back primary rain forests, and land abandonment causes the development of secondary forest ecosystems (Wright 2005), which differ in structure and species composition (Johns 1997; Laurance 2007). As secondary forests become more prevalent in the tropics, it is of increasing importance to explore their inherent ecosystem processes as well as community compositions and whether they meet the ecological importance of primary forests (Daily 2001; Vandermeer and Perfecto 2007; Liebsch et al. 2008). This is especially true in the light of the current biodiversity crisis, which is primarily linked to habitat conversion (Pimm et al. 1995; Laurance and Wright 2009). Studies on alterations of biodiversity resulting from anthropogenic influence have typically focused on invertebrates (e.g. Floren and Linsenmair 2005; Barlow et al. 2007a; Gardner et al. 2008). However, if we are to understand the ecology and conservation value of secondary forests, their suitability for vertebrates also needs to be assessed (e.g. Gray et al. 2007; Barlow et al. 2007b).

Most tamarins, genus Saguinus, are distributed throughout the Amazon Basin and have been variably considered as habitat generalists, preferring a mix of forest types (Garber 1993), or specialists preferring secondary and successional forest and edge habitat (Rylands 1996). A higher abundance of invertebrate prey - which represents a substantial component of tamarin diets besides exudates and fruits (Peres 1993; Nickle and Heymann 1996) — in secondary 
and edge forest is supposed to lead tamarins to prefer such forest types (Bernstein et al. 1976; Terborgh 1983; Yoneda 1984a; Schwarzkopf and Rylands 1989; Rylands 1996). Since tamarins may promote natural forest regeneration of secondary forests as important seed dispersers (Culot et al. 2010), it is essential to study whether, and how, tamarins utilize this forest type. However, prey foraging and capture rates of tamarins have never been compared between primary and secondary forest or forest edge.

Based on the assumption that tamarins benefit from utilization of secondary forest, we hypothesised that prey foraging and capture rates would be higher in secondary forest than in primary forest. For this, we compared activity budgets, diet compositions, prey foraging strategies, capture techniques and rates of a group of saddleback tamarins, Saguinus nigrifrons - a recent revision has elevated Saguinus fuscicollis nigrifrons to species rank (Matauschek et al. 2011) — living in primary forest with a group that had access to a 10-year-old secondary forest in Amazonian Peru.

\section{Methods}

\section{Study site}

The study was carried out at the Estación Biológica Quebrada Blanco (EBQB) between March 14 and June 27, 2011. The EBQB is located in north-eastern Peru $\left(4^{\circ} 21^{\prime} \mathrm{S}\right.$, $73^{\circ} 09^{\prime} \mathrm{W}$ ) on the right bank of Quebrada Blanco, a whitewater affluent of the Rio Tahuayo, at an altitude of $110-140 \mathrm{~m}$ asl. The majority of the study area is primary terra firme forest with embedded swampy sections. The southern study area includes a secondary forest originating from former agricultural use (first for crop cultivation, later as buffalo pasture). Since 2001 the pasture has remained unused and regenerates, with typical pioneer plants like Cecropia sp. dominating the tree layer.

In June 2011 we surveyed the vegetation structure in nine randomly selected points in each of the two habitats. Vegetation cover - estimated visually within a radius of $10 \mathrm{~m}$ around the sampling point - was higher in primary than in secondary forest in all forest strata above $5 \mathrm{~m}$ height (Online Resource Fig. S1a). Estimated epiphyte coverage was $2.9 \pm 2.9 \%$ (mean \pm SD) in primary and $0.9 \pm 1.0 \%$ in secondary forest, dominated by Araceae and Bromeliaceae (Wörner 2007). Other structure parameters were recorded with angle count-sampling (Bitterlich 1952, Kramer and Akça 2008) using Kramer's dendrometer under a basal area factor of $k=2$. We subtracted the influence of inclination and re-measured trunks at the threshold. Primary and secondary forest composition consisted of 86.8 and $92.1 \%$ trees, 4.4 and $1.4 \%$ palms, 0.7 and $0.0 \%$ lianas, as well as 8.1 and $6.5 \%$ deadwood, respectively (Online Resource Fig. S1b). While the secondary forest is dominated by trees with $d b h<15 \mathrm{~cm}$ (diameter at breast-height), tree size composition in primary forest showed a relatively even distribution (Online Resource Fig. S1c). In addition, we calculated mean heights of $24.5 \pm 3.1$ and $18.1 \pm 2.7 \mathrm{~m}$, total basal area of $29 \mathrm{~m}^{2} / \mathrm{ha}$ and $16.7 \mathrm{~m}^{2} / \mathrm{ha}$, and stand density (for trees with $d b h>5 \mathrm{~cm}$ ) of 2,495 trees/ha and 2,443 trees/ha for primary and secondary forest, respectively.

Mean annual rainfall in 2011 was about 2,300 mm (measured at Tamshiyacu, $40.4 \mathrm{~km}$ north of the EBQB, data provided by the Servicio Nacional de Meteorologia e Hidrologia del Peru). Our study period corresponded to the wet season, with maxima in April $(269 \mathrm{~mm})$ and May (368 $\mathrm{mm})$, and the transition between late wet season and beginning of a drier season starting in June (181 mm).

\section{Study groups}

We observed two groups of $S$. nigrifrons in blocks of 6 subsequent days in a regular weekly change. Group 1 (3 adults, 1 subadult and 2 infants born in February) had access to secondary forest. Group 3 (2-3 adults, one of which died in April, 2 subadults and 2 infants born in May) lived directly north of group 1 solely in primary forest and served as a reference group to control for group-specific patterns when comparing foraging behaviour of group 1 in primary and secondary forest.

Observation usually started from 0600 hours, when the tamarins left a sleeping site, and continued until the afternoon at about 1600 hours, when they entered another sleeping site. In total, group 1 was observed for $202 \mathrm{~h}$ over 28 days and group 3 for 191 h over 29 days. Both groups formed stable mixed-species troops with moustached tamarins Saguinus mystax and were well habituated to the presence of human observers.

\section{Observational methods}

We used three different methods to collect behavioural data from the study groups, excluding infants. Instantaneous scan-sampling (Martin and Bateson 2007) at 15-min intervals focused on activity budget and diet composition. We recorded the type of activity (locomotion, resting, social interaction, prey searching, fruit feeding, exudate feeding, prey feeding, other) of each tamarin that became visible within $30 \mathrm{~s}$ after the scan sampling-point indicated by the beep of a timer. We obtained 745 activity records for group 1 (681 in primary, 64 in secondary forest), and 655 for group 3. At each scan-sample point, we recorded the group position using a Garmin GPSMap 76CSx. Between scan-sampling points, focal sampling with continuous recording (Martin and Bateson 2007) was employed to 
record prey searching strategies, capture techniques, prey characteristics and capture rates. The length of focal samples was $10 \mathrm{~min}$, during which the focal individual had to be visible for at least $5 \mathrm{~min}$. The selection of focal individuals followed a previously set rotational scheme. If we could not find the individual at the top of the scheme within 2 min, we selected the next individual. If this could not be found either, we started a new search again with the previous individual. By using this procedure we ensured an even distribution of the number of focal protocols over all studied individuals. We recorded $66.7 \mathrm{~h}$ of focal sampling for group $1(61.0 \mathrm{~h}$ in primary and $5.7 \mathrm{~h}$ in secondary forest) and $55.7 \mathrm{~h}$ for group 3. During focal sampling the same activities as in scan sampling were registered. Additionally, we recorded support type and orientation as well as substrate type and height during prey search. We also categorized the technique of each successful prey capture: direct capture from open microhabitats, low intensity manipulation, e.g. opening epiphytes or unrolling dry leaves, and high intensity manipulation including breaking or biting open substrates (see also Nadjafzadeh and Heymann 2008). If captured directly, we registered whether this arose from prey flushing, meaning events where prey items fled from other tamarins. Also, we recorded colour and size of prey items. We defined prey capture success $\left(S_{i}\right)$ as the rate of captures per prey search time in focal samples. Outside of focal and scan sampling, other prey feeding events were recorded noting group, forest type, date, time and prey type, with as much detail as possible. We collected prey items discarded by the tamarins, e.g. orthopteran tegmina and hind wings, for later identification. To increase interobserver reliability, especially on height and in situ prey size estimation, we carried out a multi-week tutorial with the field assistants prior to data collection.

\section{Prey abundance}

We concentrated our survey of potential prey abundances in primary and secondary forest on nocturnal katydids since this is the dominant part of the tamarins' prey (Nickle and Heymann 1996; Smith 2000; Nadjafzadeh and Heymann 2008). Katydids belong to the family Tettigoniidae, order Orthoptera, and produce distinct species-specific stridulation sounds. Therefore, we recorded prey abundance as the number of singing orthopteran individuals on three randomly placed 50-m transects in primary and secondary forest, respectively. All transects were walked with the same velocity within 10 min using a Petersson D200 heterodyne ultrasonic detector during rainless nights. To account for species-specific activity patterns (Belwood 1990; Nickle and Heymann 1996) we repeated the survey at three different times (1900, 2300 and 0300 hours) once a month from March to June.
Data analyses

We carried out statistical analyses with R 2.12.1 (R Development Core Team 2010) using the packages stats, vegan (Oksanen et al. 2011), and lme4 (Bates et al. 2011). For the analyses of activity budgets and diet composition, only complete observation days were used. We used Fisher's exact test to compare activity budgets, diet composition, prey searching strategies and capture techniques between groups and habitat types. The function fisher.test in R uses a subroutine (FEXACT) to execute Fisher's exact tests on contingency tables larger than $2 \times 2$ (Mehta and Patel 1986; Clarkson et al. 1993). All tests were two-tailed at a significance level of $\alpha<0.05$. For each test where the null hypothesis had to be rejected, we performed additional multiple testing to obtain specific information about diverging categories. We used the Bonferroni correction to correct the significance level in multiple tests.

Due to unequal numbers and variances in the comparative analysis of prey size, we employed Welch's unequal variance $t$-test with previously ranked values instead of Mann-Whitney $U$-test (Ruxton 2006).

We analysed the diurnal distribution of secondary forest utilization of group 1 and compared it with diurnal patterns in fruit feeding and prey search.

We calculated the overlap of captured prey items between groups based on Morisita's unmodified index of similarity without log-transforming data (Krebs 1999):

$C=\frac{2 \sum p_{i j} p_{i k}}{\sum^{n} p_{i j}\left[\left(n_{i j}-1\right) /\left(N_{j}-1\right)\right]+\sum^{n} p_{i k}\left[\left(n_{i k}-1\right) /\left(N_{k}-1\right)\right]}$,

where $C$ is Morisita's index, $p_{i j}$ and $p_{i k}$ are the proportions of prey item $i$ in the total prey used by groups 1 and 3 , respectively, $n_{i j}$ and $n_{i k}$ are the numbers of individuals that use prey item $i$ in groups 1 and 3, respectively, and $N_{i}$ and $N_{k}$ are the total numbers of individuals in each group. This index produces a minimum bias of abundance and diversity in different data sets (Wolda 1981; Smith and Zaret 1982).

For taxonomic identification of collected prey items, we used literature (Beier 1962; Belwood 1990; Nickle and Castner 1995; Nickle and Heymann 1996; Bartlett and Bartlett 2003), the species online files for Orthoptera (http:// orthoptera.speciesfile.org) and Phasmida (http://phasmida. speciesfile.org), a reference collection of tamarin prey provided by Andrew C. Smith (see also Smith 2000) as well as assistance by experts for Orthoptera, Holger Braun (División Entomología, Museo de La Plata, Argentina), and Phasmida, Sven Bradler (Johann-Friedrich-Blumenbach Institute of Zoology, Göttingen, Germany). Where exact taxonomic identification was not viable due to insufficient prey remains, the items were classified into morphotypes using colour and size as categories. 
We assessed prey abundance using the generalized linear mixed model function lmer (Bates et al. 2011) with a significance level at $p<0.05$. We set night-time as random, forest type and month as fixed effects.

GPS positions were processed in ESRI ArcGIS 9.3. We performed fixed kernel home-range estimation following Worton (1989) with the software extension 'Home-RangeTools' (Rodgers et al. 2007). To analyse habitat utilization, we calculated intensities of primary and secondary forest habitat use indices $\left(H_{i}\right)$ for group 1 , basically following Neu et al. (1974):

$H_{i}=\log \frac{\text { freq }_{\text {obs }}}{\text { freq }_{\text {exp }}}$

This method compares the frequencies between observed and expected values for each habitat type. Observed frequencies were obtained from recorded GPS positions. A buffering of these points by $5 \mathrm{~m}$ represents the distribution of the tamarin group in the field and converts the point data to polygon. Krebs (1999) suggested using habitat type availability as expected frequencies. Thus, we calculated the proportions of forest types within the home range of group 1 based on the $100 \%$ minimum convex polygon (MCP) (Mohr 1947), which we also buffered by $5 \mathrm{~m}$. We log-transformed the term to get an index value between -1 (avoidance) and +1 (preference). Differences between expected and observed frequencies were tested using Fisher's exact test.

All presented statistical information were referred to Fisher's exact test, except where otherwise stated.

\section{Results}

Home-range and habitat use

Home-range size (95\% kernel, based on 740 GPS positions) was 28.6 ha for group 1 and 29.0 ha for group 3 (619 GPS positions); core areas (50\% kernel) were 8.0 and 6.7 ha, respectively (Fig. 1).

Over the entire study period, group 1 showed no clear preference or avoidance of primary or secondary forest (Fig. 2). However, comparing the seasonal utilization rates, we detected a significant increase of secondary forest use in the late wet season $(p=0.040)$.

\section{Activity budget and diet composition}

Groups 1 and 3 did not differ in activity budgets ( $p=0.723$; Online Resource Fig. S2). There was also no difference between group 1 in primary forest only and group 3 ( $p=0.728)$, and between group 1 in primary vs secondary forest $(p=0.466)$. Time allocated to prey

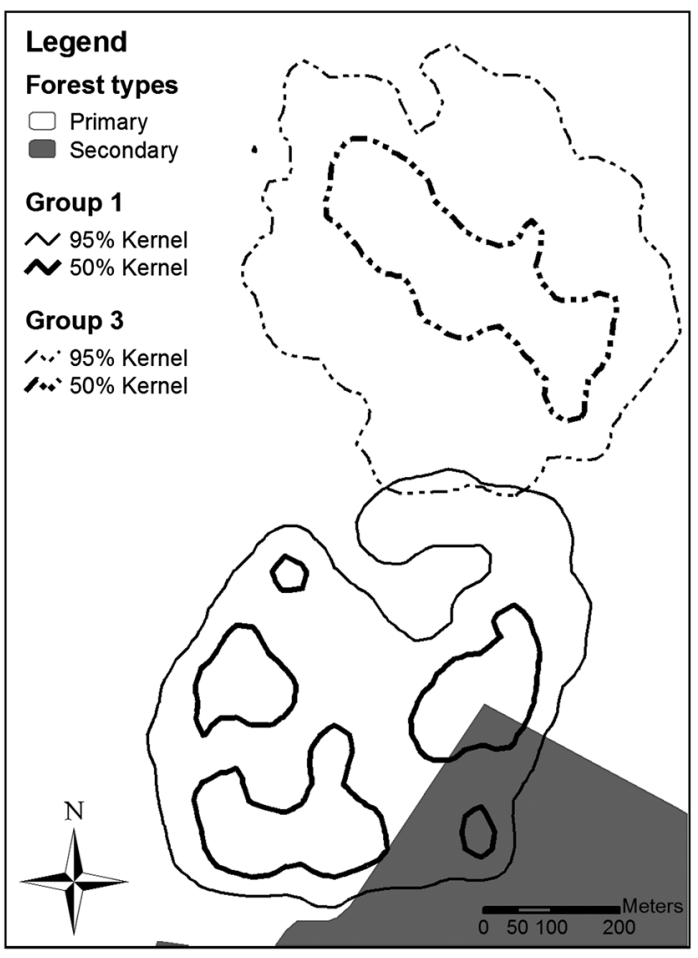

Fig. 1 Study area and kernel home ranges of groups 1 and 3 (smoothing factor $h=25$ )

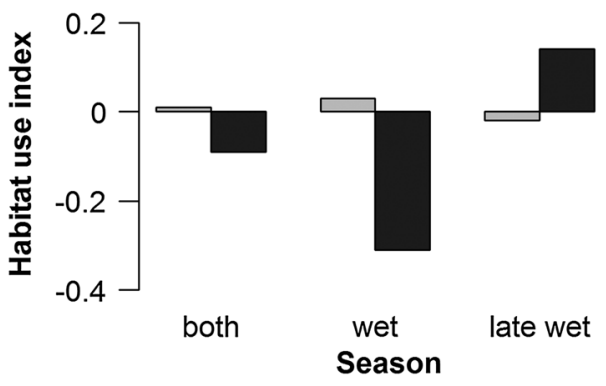

Fig. 2 Habitat use indices of group 1 for primary (light grey) and secondary forest (dark grey) in different seasons

search tended to be higher in secondary forest but the difference was not significant.

Diet composition of group 1 varied significantly between forest types $(p<0.001)$ with more fruit $(p<0.001)$ and less exudate feeding $(p=0.043)$ in secondary forest across both seasons (Fig. 3). No prey feeding was recorded in secondary forest during scan sampling. Compared to the wet season, group 1 consumed fewer fruits $(p<0.001)$ and more exudates $(p<0.001)$ in the late wet season.

Prey searching strategies

Prey search strategies did not differ (Figs. 4, 5) between groups 1 and 3 ( $p=$ n.s. in all categories; prey search time 


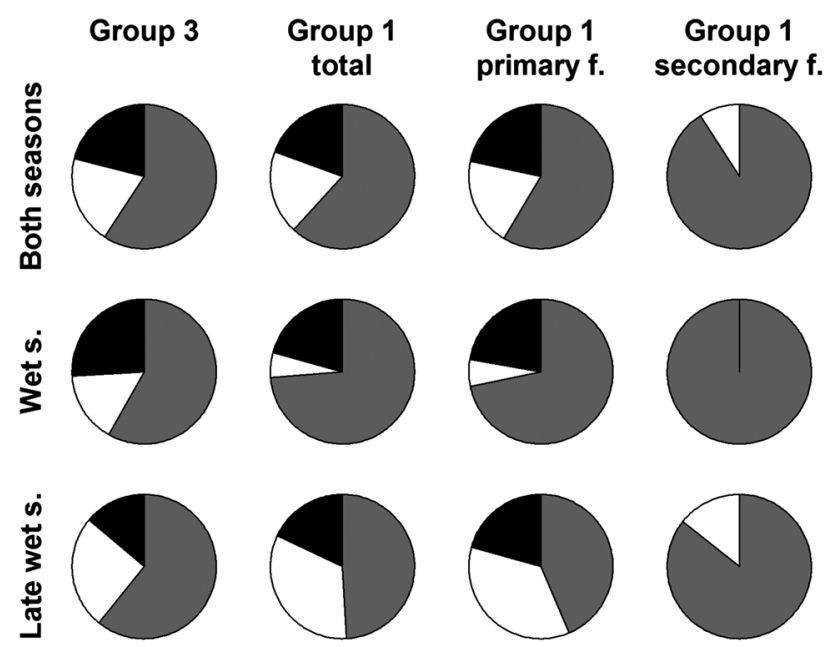

Fig. 3 Diet composition of both groups in different forest types and seasons; grey: fruit, white: exudate, black: prey; data based on scan sampling

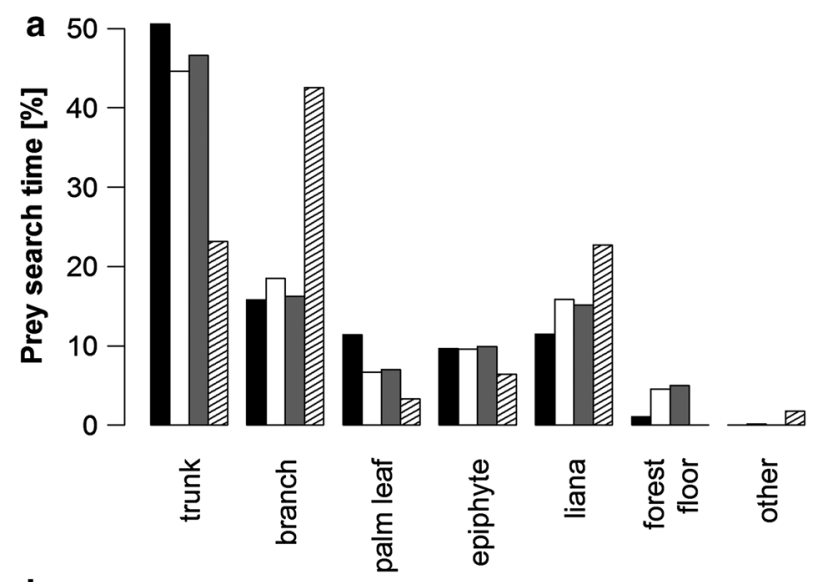

b

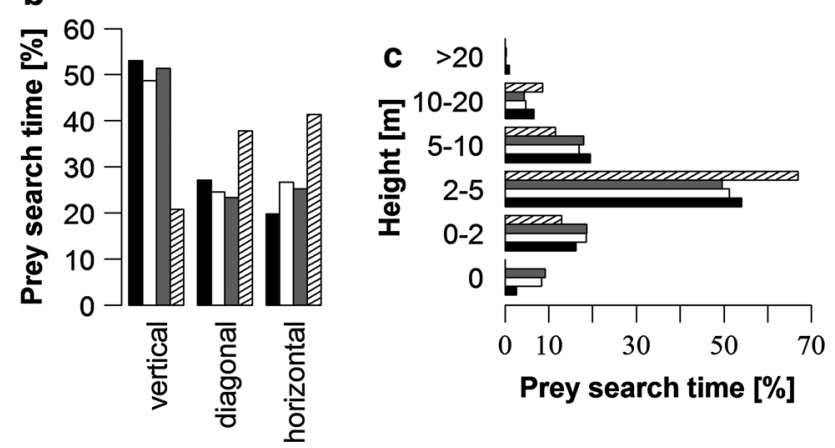

Fig. 4 a type of support, $\mathbf{b}$ support orientation and $\mathbf{c}$ height used for prey foraging in group 3 (black), group 1 (white), group 1 in primary (grey) and secondary forest (striped) only

group 1: $541 \mathrm{~min}$; group 3: $315 \mathrm{~min}$ ) or group 1 in primary forest only $(p=$ n.s. in all categories; prey search time group $1_{\text {prim }}$ : $495 \mathrm{~min}$ ). Prey searching in group 1 varied significantly between secondary and primary forest in support ( $p<0.001$; prey search time group $1_{\mathrm{sec}}$ : $\left.46 \mathrm{~min}\right)$,

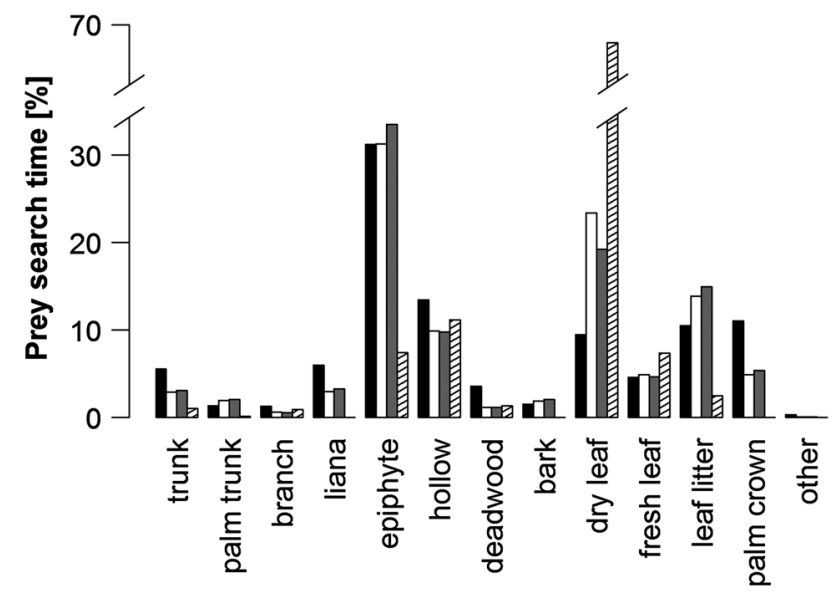

Fig. 5 Substrates searched for prey in group 3 (black), group 1 (white), group 1 in primary (grey) and secondary forest (striped) only

orientation $(p<0.001)$, substrate $(p<0.001)$ and height $(p=0.020)$. In the secondary forest trunks were used less $(p<0.001)$ and branches more intensively $(p<0.001)$ as a support, but never the forest floor. Consequently, orientation of support was less often vertical $(p<0.001)$ in the secondary forest. In the secondary forest, group 1 searched more intensively in dry leaves $(p<0.001)$ and less in epiphytes $(p<0.001)$ and leaf litter $(p=0.005)$ than in the primary forest.

Prey capture techniques

Prey capture techniques and prey characterization did not differ between groups 3 and 1 ( $p=$ n.s. in all categories; $n_{1}=91 ; n_{3}=42$ capture events; see also Online Resource Fig. S3) or group 1 in primary forest only $(p=$ n.s.; $n_{1 \text { prim }}=86$ ). Due to a small number of prey captures during focal sampling in the secondary forest $\left(n_{1 \mathrm{sec}}=5\right)$, we have not conducted statistical comparisons. However, high intensity manipulation, prey flushing events and captures of green prey items were not observed in secondary forest.

Prey items captured by group 3 were significantly larger than those captured by group 1 in total $\left(x_{1}=3.6 \pm 2.7 \mathrm{~cm}\right.$; $x_{3}=4.7 \pm 3.4 \mathrm{~cm}$; Welch's $t$-test: $t=2.79 ; d f=181.04$; $\left.p=0.004 ; n_{1}=177 ; n_{3}=99\right)$ and for the portion of primary forest $\left(x_{1 \text { prim }}=3.7 \pm 2.8 \mathrm{~cm}\right.$; Welch's $t$-test: $\left.t=3.37 ; d f=179.16 ; p=0.011 ; n_{1 \text { prim }}=163\right)$. Moreover, prey captured by group 1 in secondary forest was significantly smaller than in primary forest $\left(x_{1 \mathrm{sec}}=2.4 \pm 1.0 \mathrm{~cm}\right.$; Welch's $t$-test: $\left.t=12.04 ; d f=62.78 ; p<0.001 ; n_{1 \mathrm{sec}}=14\right)$. In total, captured prey was almost twice as big when it arose from prey flushing $\left(x_{\text {flushed }}=5.0 \pm 3.3 \mathrm{~cm} ; x_{\text {notflushed }}=2.9 \pm 2.2 \mathrm{~cm}\right.$; Welch's $t$-test: $t=4.12 ; d f=40.51 ; p<0.001 ; n_{\text {flushed }}=24$; $n_{\text {notflushed }}=79$ ). 
Table 1 Substrates of prey items captured by group 1 (primary and secondary forest) and group 3 during focal sampling

\begin{tabular}{|c|c|c|c|c|c|c|c|c|}
\hline & \multicolumn{2}{|c|}{ Group 3} & \multicolumn{2}{|c|}{ Group 1} & \multicolumn{2}{|c|}{$\begin{array}{l}\text { Group } 1 \text {, } \\
\text { primary } \\
\text { forest }\end{array}$} & \multicolumn{2}{|c|}{$\begin{array}{l}\text { Group 1, } \\
\text { secondary } \\
\text { forest }\end{array}$} \\
\hline & No. & $\%$ & No. & $\%$ & No. & $\%$ & No. & $\%$ \\
\hline Trunk & 5 & 11.9 & 10 & 11.0 & 9 & 10.5 & 1 & 20.0 \\
\hline Palm trunk & - & - & - & - & - & - & - & - \\
\hline Branch & 1 & 2.4 & - & - & - & - & - & - \\
\hline Liana & 1 & 2.4 & 1 & 1.1 & 1 & 1.2 & - & - \\
\hline Epiphyte & 6 & 14.3 & 16 & 17.6 & 15 & 17.4 & 1 & 20.0 \\
\hline Hollow & 12 & 28.6 & 10 & 11.0 & 10 & 11.6 & - & - \\
\hline Deadwood & 1 & 2.4 & - & - & - & - & - & - \\
\hline Bark & 2 & 4.8 & 1 & 1.1 & 1 & 1.2 & - & - \\
\hline Dry leaf & 2 & 4.8 & 14 & 15.4 & 13 & 15.1 & 1 & 20.0 \\
\hline Fresh leaf & 1 & 2.4 & 10 & 11.0 & 8 & 9.3 & 2 & 40.0 \\
\hline Leaf litter & 11 & 26.2 & 28 & 30.8 & 28 & 32.6 & - & - \\
\hline Palm canopy & - & - & 1 & 1.1 & 1 & 1.2 & - & - \\
\hline Other & - & - & - & - & - & - & - & - \\
\hline Total & 42 & 100 & 91 & 100 & 86 & 100 & 5 & 100 \\
\hline
\end{tabular}

Data shown in Table 1 were obtained from the type of substrate where a prey item was captured. The types of microhabitat group 3 searched prior to captures differed significantly from those of group $1(p<0.001)$ and group 1 in primary forest $(p=0.002)$. Due to insufficient numbers in the categories to test, we have not conducted further statistical analysis. However, both groups reached relatively high capture rates in leaf litter, epiphytes and hollows, such as knotholes.

\section{Diurnal variation of habitat use and foraging behaviour}

Group 1 showed preference for secondary forest in the first $2 \mathrm{~h}$ of the day (Fig. $6 \mathrm{a} ; H_{\mathrm{sec}}=0.49 ; H_{\text {prim }}=-0.14$; $p<0.001 ; n=129$ GPS positions) and avoidance during the rest of the day (significant for 1200-1400 hours: $H_{\text {sec }}=-0.73 ; H_{\text {prim }}=0.04 ; p=0.010 ; n=156$ GPS positions). The distribution of fruit feeding in group 1 over the day went in parallel with secondary forest utilization, but prey search peaked between 1000 and 1400 hours when secondary forest use was low (Fig. 6b). The diurnal distribution of fruit feeding and prey search did not differ between groups 1 and 3 (fruit: $p=0.982$; prey search: $p=0.588$ ), thus, group-specific idiosyncrasies for patterns observed in group 1 can be excluded.

Because habitat utilization in group 1 showed a diurnal variation, we compared the activity budget and prey search strategies in group 1 of the periods $0600-0800$ and 0800-1600 hours. To control for forest type, we excluded secondary forest data from the analysis. In the early morning hours the tamarins travelled more $(p=0.003$;
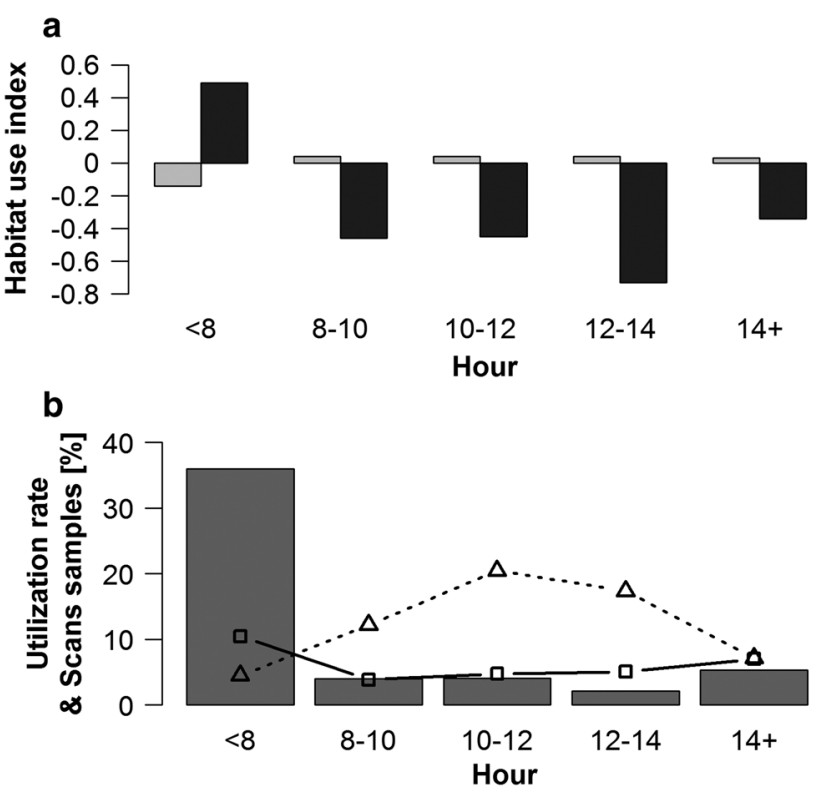

Fig. 6 Diurnal variation of a habitat use of primary (grey) and secondary forest (black); b secondary forest utilization (bars), prey search (triangles and dotted line) and fruit feeding (squares and solid line) activity in group 1

$n_{\text {bef8 }}=89 ; n_{\text {aft8 }}=592$ activity records) but showed less prey searching activity $(p<0.001)$ than during the rest of the day. Prey searching varied significantly during the daytime in substrates $(p=0.04$; prey search time before 0800 hours: $29 \mathrm{~min}$; after 0800 hours: $466 \mathrm{~min}$ ) but not in support, orientation and height. We did not test for diurnal differences in prey capture techniques due to insufficient sample sizes in the early morning hours $\left(n_{\text {bef8 }}=6\right)$.

\section{Prey spectrum}

Orthopterans were the most dominant prey items (Online Resource Table S1), independent of group (group 1: $74 \%$; group 3: $77 \%$ ) or forest type (secondary forest: $69 \%$; primary forest: $74 \%$ ). Additionally, both groups consumed small portions of Araneida, Scorpionida, Vertebrata and Phasmatodea. Only group 3 captured Coleoptera, whereas group 1 uniquely fed on Blattodea, Mantodea and eggs of Araneida. The tettigoniid Typophyllum mortuifolium was only recorded in secondary forest. A Morisita Index of 0.852 (excluding unidentified prey: 0.763 ) indicates a high overlap of prey items comparing group 3 and the portion of primary forest in group 1 . This value decreases slightly to 0.816 (excluding unidentified prey: 0.727 ) when adding the prey items of secondary forest. Both comparisons show significant differences (both $p<0.001$; excluding unidentified prey: both $p<0.001)$. Prey spectrum did not differ between secondary and primary forest $(p=0.836$; excluding unidentified prey: $p=0.965$ ). 
Prey capture rate

Group 1 was more successful in prey capturing than group $3\left(S_{1}=10.1 \mathrm{ind} / \mathrm{h}_{\text {preysearch }} ; S_{3}=8.0 \mathrm{ind} / \mathrm{h}_{\text {preysearch }}\right)$. In primary forest the prey capture rate of group 1 was higher $\left(S_{1 \text { prim }}=10.4 \mathrm{ind} / \mathrm{h}_{\text {preysearch }}\right)$ than in secondary forest $\left(S_{1 \mathrm{sec}}=6.5 \mathrm{ind} / \mathrm{h}_{\text {preysearch }}\right)$.

Prey abundance

The number of calling Orthoptera was significantly higher in secondary than in primary forest $\left(N_{\text {prim }}=11.2 \pm 2.5\right.$; $N_{\mathrm{sec}}=15.1 \pm 4.4$; lmer: $\left.z=34.53 ; p<0.001\right)$. There was a significant influence of month, with highest numbers in June $\left(N_{\text {June }}=16.5 \pm 5.0 ;\right.$ lmer: $\left.z=33.52 ; p<0.001\right)$. We excluded the interaction term between forest type and month from the final model due to a non-significant influence.

\section{Discussion}

\section{Utilization of forest types}

In contrast to other studies on the ranging behaviour of the genus Saguinus (Bernstein et al. 1976; Yoneda 1984a; Schwarzkopf and Rylands 1989; Vulinec et al. 2006), we could not detect a general preference of secondary forest by group 1. These differences could mainly reflect a variable definition of the term 'secondary forest' with a wide range of age classes and vegetation types from which the studied forest developed. Clear-cutting, for instance, generally eliminates most species from a site and destroys soil structure and nutrient capital, while selective logging and similar human interferences maintain these structural parameters to a greater or lesser extent (Corlett 1994). In turn, a former use of land as plantation can lead to influences on species composition through introduced crops (Chokkalingam and De Jong 2001). Thus, starting conditions, such as the former type of vegetation or anthropogenic exploitation, influence the succession and recovery rate. These patterns are also linked to the age of the secondary forest, which highly affects productivity rates and material flows within the forest system (Brown and Lugo 1990). Comparisons between studies in regard to the intricacy of the term 'secondary forests' should therefore be made with caution. Among the previously listed studies, only Bernstein et al. (1976) worked in a comparable secondary forest younger than 10 years that emerged on a clear-felled area, but their findings on habitat utilization of tamarins were supported by only six sightings. Indeed, for S. nigrifrons, Culot (2009) showed that during the early stages of forest succession, the frequencies of visits by tamarins increased gradually.
Our results revealed marked differences in the prey foraging behaviour of $S$. nigrifrons between primary and secondary forest. However, these do not seem to be due to group-specific characteristics of group 1, because its activity budget and diet composition did not differ noticeably compared to group 3 .

Although prey was not represented in the diet composition in secondary forest, we recorded prolonged prey searching activities, which is in line with other studies (Bernstein et al. 1976; Terborgh 1983; Yoneda 1984a; Schwarzkopf and Rylands 1989; Rylands 1996). This might be due to less (albeit not significantly) frequent resting and social activities, which were mainly reduced to stops during heavy rain and scent-marking behaviour close to the homerange boundaries, indicating predation-sensitive behaviour (Garber and Bicca-Marques 2002). Indeed, the structural deficiency in secondary forest, especially the lack of a closed canopy, increases the risk of predation by raptors (Vidal and Cintra 2006; Oliveira and Dietz 2011), which is a substantial threat to tamarins (Terborgh 1983; Heymann 1990b).

The topographical position might also have influenced prey foraging intensity. The secondary forest was located along the home-range boundary of group 1. Peres (1992a) found that saddleback tamarins spend more time searching for prey close to the boundaries of their range, presumably to minimize food loss due to prey foraging by neighbouring groups in overlap areas of the home-range. This investment in time and energy is a result of territorial defence and, therefore, independent of the actual quality of the foraging site.

In accordance with Lopes and Ferrari (1994), we observed that the tamarins frequently used the periphery of abundant fruit sources for prey search activities. Regularly the individuals of $S$. nigrifrons had to wait for their congeners to finish feeding because $S$. mystax holds the dominant position within the mixed-species troop, allowing the first access to fruiting trees (Heymann 1990a; Peres 1992a). Besides, saddlebacks used the movements to and away from the fruit source for prey search ('travel foraging') instead of fast locomotion. Although the visits to secondary forest were not motivated by the prospect of prey search, the behaviour of the tamarins actually led to an increase of prey search activity within the time budget.

The seasonal variation in the utilization of the secondary forest is in line with the findings of Culot (2009) at the same study site during the same seasons. Culot (2009) argued that the secondary forest provides fruit sources in times of fruit scarcity. Indeed, in June fruit feeding slightly increased in the secondary forest, and especially during the first two hours of the day it was used as a preferred fruit foraging area. Smith (2000) argued that due to low energy levels at the beginning of the day, tamarins urgently need a source of fast energy. Thus, tamarins usually visit abundant 
fruit sources, which become rare in the dry season (Lopes and Ferrari 1994; Peres 1994; Culot 2009). Although the tamarins always slept outside of the secondary forest, in June they headed for one such tree every morning directly after rising, which indicates the importance of abundant fruit sources in times of fruit scarcity.

That the tamarins mainly visited secondary forest during the morning hours may also be a result of microclimatic changes during the day. While the closed canopy in primary forest provides an effective protection against direct solar radiation, the more open vegetation in secondary forest increases the risk of hyperthermia, especially in the drier months with fewer clouds, and during midday and early afternoon (Hill 2005).

On the one hand, the strong diurnal variation of secondary forest use illustrates the selective utilization of that habitat type by S. nigrifrons. On the other hand, it may also influence the patterns found in prey foraging behaviour within the secondary forest. However, even though we may not exclude time of day as a possible influence on saddleback prey foraging, there is also no indication for such an effect, neither in our data nor in the literature.

Our results contradict the assumption that saddleback tamarins benefit from increased prey abundances because of higher proportions of fresh leaves during the early regrowth stages of secondary forests (Schwarzkopf and Rylands 1989; Peres 1992b; Rylands 1996). Although we recorded higher densities of Orthoptera in secondary forest, the tamarins fed on these much less than in primary forest. On the one hand, this could be due to methodical reasons: the thicker foliage of primary forests can obstruct the oscillations of ultrasounds, such as orthopteran stridulations (Diwakar and Balakrishnan 2007). This is especially true for the Pseudophyllinae that belong to the preferred prey of S. nigrifrons (Peres 1993; Smith 2000; Online Resource Table S1) and often perform high-frequency stridulation (Montealegre et al. 2006). On the other hand, however, this may also be caused by varying species compositions between forest types. Using arboreal ants as model organisms, Floren and Linsenmair (2005) showed that in tropical secondary forests usually only a few species become dominant. Barlow et al. (2007a) demonstrated for grasshoppers (Orthoptera; Acridiidae) that $<40 \%$ of primary forest species occurred in secondary forest and $<10 \%$ of species were unique to it, which is mainly due to higher temperatures (Ruiz-Guerra et al. 2012) or missing microhabitats serving as diurnal shelters, like palms or epiphytes (Belwood 1990). Thus it is likely that, although the overall prey abundance increases in secondary forest, the potential prey diversity decreases. As we know that $S$. nigrifrons consumes only a fraction of the more than 300 orthopteran species (Nickle and Heymann 1996; Smith 2000) native to north-eastern Peru (Nickle and Castner
1995), the restricted food resource of orthopteran prey (Peres 1993; Nickle and Heymann 1996) seems to be even more limited in secondary forest.

\section{Patterns of prey foraging influenced by forest type}

Our findings on prey search strategies and capture techniques in both groups are in accordance with other studies (e.g. Terborgh 1983; Peres 1993; Nadjafzadeh and Heymann 2008). Thus, in general, S. nigrifrons is a highly manipulative forager of the lower forest strata, using a wide range of different support types and substrates. Relatively long slender hand shapes enable saddleback tamarins to exploit concealed microhabitats, like epiphytes and knotholes (Garber 1991; Bicca-Marques 1999), mainly for large prey items, while elongated fore- and hindlimbs facilitate movement and foraging in the lower forest strata through 'clinging and leaping' from trunk to trunk (Garber and Leigh 2001). We found no differences in prey search strategies and capture techniques between group 3 and group 1 as well as group 1 in primary forest only, but great differences between forest types.

In secondary forest we never observed tamarins on the forest floor. The avoidance of this microhabitat could be one reason for the low capture rate in secondary forest since most prey, especially concealed Orthoptera, jump to the ground to hide in leaf litter when detected by predators (Peres 1992b; Nickle and Castner 1995). In contrast, group 1 obtained nearly one third of the captured prey items from the forest floor in primary forest. Besides open canopy, a dense understorey, as found in secondary forest, raises the predation risk in tamarin groups as a consequence of poor visibility of predators, such as felids and snakes (Vidal and Cintra 2006). Since prey flushing is a prevailing benefit for S. nigrifrons in mixed-species troops (Peres 1992b), a general absence of captures of flushed prey would be noteworthy. In a study on the same tamarin species combination, flushed prey made up for more than $40 \%$ of captured items and $70 \%$ of captured biomass of saddlebacks (Peres 1992b). This is also in line with the larger size of flushed prey we found, and highlights its importance for the protein uptake of saddlebacks.

The diversity of substrates utilized by S. nigrifrons for prey search markedly decreased in the poorly heterogeneous vegetation of the secondary forest. Generally, $S$. nigrifrons intensively exploits bromeliads like Guzmania vittata and G. lingulata for prey foraging (Peres 1993; this study). However, epiphytes and palms, as well as lichen and mosses, which are important for many Pseudophyllinae to conceal themselves during the day (Belwood 1990; Nickle and Heymann 1996), need comparatively more time to establish than pioneer vegetation and are thus sparsely distributed in young regrowth forests (Costa 1999; Wörner 
2007; Online Resource Fig. S1). As a result, the saddlebacks almost exclusively - albeit not successfully explored dried curled leaves for prey, which are abundant in secondary forest due to a dominance of the pioneer tree Cecropia sp. that produces large short-lived leaves (Clark and Clark 1992).

In general, prey capture success was much lower in secondary than in primary forest. Assuming that prey accessibility determines capture success (Terborgh 1983), the secondary forest appears to be an unsuitable habitat for prey foraging. In addition, S. nigrifrons mostly captured prey items of small size, mainly orthopteran instars, Grylloidae and Arachnida, in secondary forest, although it is the most specialized tamarin species in regard to large prey (Yoneda 1984b; Peres 1992b; Nickle and Heymann 1996). Moreover, Proscopiidae, which account for more than $17 \%$ of the total number of ortopteran prey items, and achieve body lengths up to $20 \mathrm{~cm}$, were not part of the prey spectrum in the secondary forest. The lack of this prey species group alone may lead to a major decline of protein uptake in secondary forest.

\section{Conclusions}

Our results represent one of the first attempts to evaluate the utilization of young secondary forest by Saguinus nigrifrons under the perspective of prey foraging. We did not find a general preference of secondary forest by saddleback tamarins. Moreover, their main motivation in visiting the secondary forest seems to be the use of abundant fruit sources. Although the time tamarins spend on prey searching is relatively longer in secondary forest, other important parameters are contrasting: no recorded prey feeding during scan sampling, low prey capture success and smaller prey sizes. Thus, we consider $S$. nigrifrons to be an opportunistic prey forager in secondary forest. This pattern is interpreted as a result of higher predation risk and poorer vegetation structure. The same factors influence the methods of prey foraging. Prey search in secondary forest is mainly reduced to exploration of dried curled leaves, while capture events emerging from prey flushing seem not to occur. In addition, the diversity of the prey spectrum and prey size both decrease significantly.

In summary, young secondary forest does not seem to serve as a suitable prey foraging habitat for $S$. nigrifrons, although this species is considered to be highly flexible in habitat utilization (Rylands 1996). It remains an open question whether this also applies for other types and ages of secondary forest. Further comparable studies in this context could also enrich the discussion on the conservation value of secondary forests (Dent and Wright 2009; Waltert et al. 2011) because this methodical approach does not (just) focus on species number and abundance as indicators for biodiversity, but rather on performances of ecological demands of species.

Acknowledgments We gratefully thank Ney Shahuano Tello and Gabriel Caritimari Arirama for their essential field assistance, Holger Braun for his helpful suggestions on detection methodology regarding Orthoptera and Andrew C. Smith for providing a reference collection of tamarin prey. D.K. was supported by a grant from the German Academic Exchange Service DAAD (D/10/52803).

Open Access This article is distributed under the terms of the Creative Commons Attribution License which permits any use, distribution, and reproduction in any medium, provided the original author(s) and the source are credited.

\section{References}

Barlow J, Gardner TA, Araujo IS, Avila-Pires TC, Bonaldo AB, Costa JE, Esposito MC, Ferreira LV, Hawes J, Hernandez MIM, Hoogmoed MS, Leite RN, Lo-Man-Hung NF, Malcolm JR, Martins MB, Mestre LAM, Miranda-Santos R, Nunes-Gutjahr AL, Overal WL, Parry L, Peters SL, Ribeiro-Junior MA, da Silva MNF, Motta C, Peres CA (2007a) Quantifying the biodiversity value of tropical primary, secondary, and plantation forests. P Natl Acad Sci USA 104:18555-18560

Barlow J, Mestre LAM, Gardner TA, Peres CA (2007b) The value of primary, secondary and plantation forests for Amazonian birds. Biol Conserv 136:212-231

Bartlett RD, Bartlett P (2003) Reptiles and amphibians of the Amazon: an ecotourist's guide. University Press of Florida, Gainesville

Bates D, Maechler M, Bolker B (2011) lme4: Linear mixed-effects models using S4 classes. R package version 0.999375-42. http:// CRAN.R-project.org/package $=1 m e 4$

Beier M (1962) Orthoptera, Tettigoniidae, Pseudophyllinae I \& II. Das Tierreich 73 \& 74. Walter de Gruyter \& Co, Berlin

Belwood JJ (1990) Anti-predator defences and ecology of Neotropical katydids, especially the Pseudophyllinae. In: Bailey WJ, Rentz DCF (eds) The Tettigoniidae. Biology, systematics and evolution. Springer, Berlin, pp 8-26

Bernstein IS, Balcaen P, Dresdale L, Gouzoules H, Kavanagh M, Patterson I, Neyman-Warner P (1976) Differential effects of forest degradation on primate populations. Primates 17:401-411

Bicca-Marques JC (1999) Hand specialization, sympatry, and mixedspecies associations in callitrichines. J Hum Evol 36:349-378

Bitterlich W (1952) Die Winkelzählprobe. Forstwiss Centralbl 71:215-225

Brown S, Lugo AE (1990) Tropical secondary forests. J Trop Ecol $6: 1-32$

Chokkalingam U, De Jong W (2001) Secondary forest: a working definition and typology. Int For Rev 3:19-26

Clark DA, Clark DB (1992) Life history diversity of canopy and emergent trees in a Neotropical rain forest. Ecol Monogr 62:315-344

Clarkson DB, Fan YA, Joe H (1993) A remark on algorithm 643: FEXACT: an algorithm for performing Fisher's exact test in $\mathrm{R} \times \mathrm{C}$ contingency tables. ACM T Math Softw 19:484-488

Corlett RT (1994) What is secondary forest? J Trop Ecol 10:445-447

Costa DP (1999) Epiphytic bryophyte diversity in primary and secondary lowland rainforests in Southeastern Brazil. Bryologist $102: 320-326$ 
Culot L (2009) Primary seed dispersal by two sympatric species of tamarins, Saguinus fuscicollis and Saguinus mystax, and postdispersal seed fate. Ph.D. thesis, University of Liège, Liège

Culot L, Muñoz Lazo FJJ, Huynen M-C, Poncin P, Heymann EW (2010) Seasonal variation in seed dispersal by tamarins alters seed rain in a secondary rainforest. Int J Primatol 31:553-569

Daily GC (2001) Ecological forecasts. Nature 411:245

Dent HD, Wright SJ (2009) The future of tropical species in secondary forests: a quantitative review. Biol Conserv 142:2833-2843

Development Core Team R (2010) R: a language and environment for statistical computing. R Foundation for Statistical Computing, Vienna

Diwakar S, Balakrishnan R (2007) Vertical stratification in an acoustically communicating ensiferan assemblage of a tropical evergreen forest in southern India. J Trop Ecol 23:479-486

FAO (2007) State of the world's forests 2007. Food and Agriculture Organization, Rome

Floren A, Linsenmair KE (2005) The importance of primary tropical rain forest for species diversity: an investigation using arboreal ants as an example. Ecosystems 8:559-567

Garber PA (1991) Comparative study of positional behavior in three species of tamarin monkeys. Primates 32:219-230

Garber PA (1993) Feeding ecology and behaviour of the genus Saguinus. In: Rylands $\mathrm{AB}$ (ed) Marmosets and tamarins: systematics, behaviour, and ecology. Oxford University Press, Oxford, pp 273-295

Garber PA, Bicca-Marques JC (2002) Evidence of predator sensitive foraging and travelling in single- and mixed-species tamarin troops. In: Miller LE (ed) Eat or be eaten: predator-sensitive foraging in primates. Cambridge University Press, Cambridge, pp 138-153

Garber PA, Leigh S (2001) Patterns of positional behavior in mixedspecies troops of Callimico goeldii, Saguinus labiatus and Saguinus fuscicollis in northwestern Brazil. Am J Primatol 54:17-31

Gardner TA, Hernández MMI, Barlow J, Peres CA (2008) Understanding the biodiversity consequences of habitat change: the value of secondary and plantation forests for Neotropical dung beetles. J Appl Ecol 45:883-893

Gray MA, Baldauf SL, Mayhew PJ, Hill JK (2007) The response of avian feeding guilds to tropical forest disturbance. Conserv Biol 21:133-141

Heymann EW (1990a) lnterspecific relations in a mixed-species troop of moustached tamarins, Saguinus mystax, and saddle-back tamarins, Saguinus fuscicollis (Platyrrhini: Callitrichidae), at the Rio Blanco, Peruvian Amazonia. Am J Primatol 21:115-127

Heymann EW (1990b) Reactions of wild tamarins, Saguinus mystax and Saguinus fuscicollis to avian predators. Int $\mathrm{J}$ Primatol 11:327-337

Hill R (2005) Day length seasonality and the thermal environment. In: Brockman DK, van Schaik CP (eds) Seasonality in primates: studies of living and extinct human and non-human primates. Cambridge University Press, Cambridge, pp 197-213

Johns AG (1997) Timber production and biodiversity conservation in tropical rain forests. Cambridge University Press, Cambridge

Kramer H, Akça A (2008) Leitfaden zur Waldmesslehre. Sauerländer, Frankfurt

Krebs CJ (1999) Ecological methodology. Addison Wesley Longman, New York

Laurance WF (2007) Have we overstated the tropical biodiversity crisis? Trends Ecol Evol 22:65-70

Laurance WF, Wright SJ (2009) New insights into the tropical biodiversity crisis. Conserv Biol 23:1382-1385

Liebsch D, Marques MCM, Goldenberg R (2008) How long does the Atlantic rain forest take to recover after a disturbance? Changes in species composition and ecological features during secondary succession. Biol Conserv 141:1717-1725

Lopes MA, Ferrari FF (1994) Foraging behavior of a tamarin group (Saguinus fuscicollis weddelli) and interactions with marmosets (Callithrix emiliae). Int J Primatol 15:373-387

Martin P, Bateson P (2007) Measuring behaviour: an introductory guide. Cambridge University Press, Cambridge

Matauschek C, Roos C, Heymann EW (2011) Mitochondrial phylogeny of tamarins (Saguinus, Hoffmannsegg 1807) with taxonomic and biogeographic implications for the S.nigricollis species group. Am J Phys Anthropol 144:564-574

Mehta CR, Patel NR (1986) A hybrid algorithm for Fisher's exact test on unordered $\mathrm{R} \times \mathrm{C}$ contingency tables. Commun Stat 15:387-403

Mohr CO (1947) Table of equivalent populations of North American small mammals. Am Midl Nat 37:223-249

Montealegre-Z F, Morris GK, Mason AC (2006) Generation of extreme ultrasonics in rainforest katydids. J Exp Biol 209:4923-4937

Nadjafzadeh M, Heymann EW (2008) Prey foraging of red titi monkeys, Callicebus cupreus, in comparison to sympatric tamarins, Saguinus mystax and Saguinus fuscicollis. Am J Phys Anthropol 135:56-63

Neu CW, Byers CR, Peek JM (1974) A technique for analysis of utilization availability data. J Wildlife Manage 38:541-545

Nickle DA, Castner JL (1995) Strategies utilized by katydids (Orthoptera: Tettigoniidae) against diurnal predators in rainforests of northeastern Peru. J Orth Res 4:75-88

Nickle DA, Heymann EW (1996) Predation on Orthoptera and other orders of insects by tamarin monkeys, Saguinus mystax mystax and Saguinus fuscicollis nigrifrons (Primates: Callitrichidae), in north-eastern Peru. J Zool 239:799-819

Oksanen J, Blanchet FG, Kindt R, Legendre P, Minchin PR, O'Hara RB, Simpson GL, Solymos P, Henry M, Stevens H, Wagner H (2011) Vegan: community ecology package. R package version 2.0-1. http://CRAN.R-project.org/package=vegan

Oliveira LC, Dietz JM (2011) Predation risk and the interspecific association of two Brazilian Atlantic forest primates in Cabruca agroforest. Am J Primatol 73:852-860

Peres CA (1992a) Consequences of joint-territoriality in a mixedspecies group of tamarin monkeys. Behaviour 123:220-240

Peres CA (1992b) Prey-capture benefits in a mixed-species group of Amazonian tamarins, Saguinus fuscicollis and S. mystax. Behav Ecol Sociobiol 31:339-347

Peres CA (1993) Diet and feeding ecology of saddle-back (Saguinus fuscicollis) and moustached (S. mystax) tamarins in Amazonian terra firme forest. J Zool 230:567-592

Peres CA (1994) Primate responses to phenological changes in an Amazonian terra firme forest. Biotropica 26:98-112

Pimm SL, Russell GJ, Gittleman JL, Brooks TM (1995) The future of biodiversity. Science 269:347-350

Rodgers AR, Carr AP, Beyer HL, Smith L, Kie JG (2007) HRT: Home Range Tools for ArcGIS. Version 1.1. Ministry of Natural Resources, Ontario

Ruiz-Guerra B, Renton K, Dirzo R (2012) Consequences of fragmentation of tropical moist forest for birds and their role in predation of herbivorous insects. Biotropica 44:228-236

Ruxton GD (2006) The unequal variance t-test is an underused alternative to Student's $t$-test and the Mann-Whitney $U$-test. Behav Ecol 17:688-690

Rylands AB (1996) Habitat and the evolution of social and reproductive behavior in the Callitrichidae. Am J Primatol 38:5-18

Schwarzkopf L, Rylands AB (1989) Primate species richness in relation to habitat structure in Amazonian rainforest fragments. Biol Conserv 48:1-12 
Smith AC (2000) Interspecific differences in prey captured by associating saddleback (Saguinus fuscicollis) and moustached (Saguinus mystax) tamarins. J Zool 251:315-324

Smith EP, Zaret TM (1982) Bias in estimating niche overlap. Ecology 63:1248-1253

Terborgh J (1983) Five New World primates. Princeton University Press, Princeton

Vandermeer J, Perfecto I (2007) The agricultural matrix and a future paradigm for conservation. Conserv Biol 21:274-277

Vidal MD, Cintra R (2006) Effects of forest structure components on the occurrence, group size and density of groups of bare-face tamarins (Saguinus bicolor Primates: Callitrichinae) in Central Amazonia. Acta Amazon 36:237-248

Vulinec K, Lambert J, Mellow DJ (2006) Primate and dung beetle communities in secondary growth rainforests: implications for conservation of seed dispersal systems. Int J Primatol 27:855-879

Waltert M, Bobo KS, Kaupa S, Montoya LM, Nsanyi MS, Fermon H (2011) Assessing conservation values: biodiversity and endemicity in tropical land use systems. PLoS ONE 6:e16238
Wolda H (1981) Similarity indices, sample size and diversity. Oecologia 50:296-302

Wörner LLB (2007) Populationsdichte und Mikrohabitatsansprüche von Guzmania vittata und Guzmania lingulata im peruanischen Tieflandregenwald. B.Sc. Thesis. Philipps-University, Marburg

Worton BJ (1989) Kernel methods for estimating the utilization distribution in home-range studies. Ecology 70:164-168

Wright SJ (2005) Tropical forests in a changing environment. Trend Ecol Evol 20:553-554

Wright SJ, Muller-Landau HC (2006) The future of tropical forest species. Biotropica 38:287-301

Yoneda M (1984a) Ecological study of the saddle-backed tamarin (Saguinus fuscicollis) in northern Bolivia. Primates 25:1-12

Yoneda M (1984b) Comparative studies on vertical separation, foraging behavior, and traveling mode of saddle-backed tamarins (Saguinus fuscicollis) and red-chested moustached tamarins (Saguinus labiatus) in northern Bolivia. Primates 25:414-422 